\title{
One-year aging effects on microtensile bond strengths of composite and repairs with different surface treatments
}

\begin{abstract}
Marcela Oliveira de SOUZA(a) Vicente Castelo Branco LEITUNE(a) Stéfani Becker RODRIGUES(a) Susana Maria Werner SAMUEL(a) Fabrício Mezzomo COLLARES(a)
\end{abstract}

(a) Universidade Federal do Rio Grande do Sul, School of Dentistry, Dental Materials Laboratory, Porto Alegre, RS, Brazil.

Declaration of Interests: The authors certify that they have no commercial or associative interest that represents a conflict of interest in connection with the manuscript.

Corresponding Author:

Fabrício Mezzomo Collares

Email: fabricio.collares@ufrgs.br

DOI: 10.1590/1807-3107BOR-2017.vol31.0004

Submitted: May 10, 2016

Accepted for publication: Oct 21, 2016

Last revision: Nov 21, 2016

\begin{abstract}
The present study aimed to evaluate effects of different surface treatments and aging of composite cylinders on bond strength of composite resin repair. Thirty-two composite cylinders were produced and divided into four groups according to type of surface treatment and storage time of composite cylinder and repair. Cylinder surface of control group $\left(\mathrm{G}_{\text {control }}\right)$ received no treatment before composite repair. Other groups were sandblasted with aluminum oxide $\left(\mathrm{G}_{\mathrm{Al} 2 \mathrm{O} 3}\right)$, followed by silane $\left(\mathrm{G}_{\mathrm{Al} 2 \mathrm{O} 3 \mathrm{sil}}\right)$ or adhesive $\left(\mathrm{G}_{\mathrm{Al2O3ad}}\right)$. Composite cylinders were stored in artificial saliva for either 24 hours or 1 year. Repairs were performed and stored in artificial saliva for 24 hours or 1 year and repair strength was evaluated using microtensile bond strength test. Data were submitted to Student's $t$ test, two-way ANOVA, and post hoc test for storage time and treatment $(\alpha=0.05)$. $G_{\text {control }}$ group showed lower values of aging of composite cylinder and storage time of repair (24 hours or 1 year for both) compared with other groups ( $p<0.05)$. $G_{\mathrm{Al} 203 \mathrm{ad}}$ and $\mathrm{G}_{\mathrm{Al2O} 3 \mathrm{sil}}$ groups did not exhibit decreased microtensile bond strength with aged repairs (1 year; $\mathrm{p}>0.05$ ). Polymer degradation was significant for composite cylinders during the first year of storage in $G_{\text {control }}$, $\mathrm{G}_{\mathrm{Al} 2 \mathrm{O} 3}$, and $\mathrm{G}_{\mathrm{Al} 2 \mathrm{O} 3 \mathrm{ad}}$ groups $(\mathrm{p}<0.05)$. In $\mathrm{G}_{\mathrm{Al} 2 \mathrm{O} 3 \mathrm{sil}}$ group, storage time of composite cylinders was not significant $(p>0.05)$. Aging of composite resin influenced bond strength of restoration repair for up to 1 year. Sandblasting with $\mathrm{Al}_{2} \mathrm{O}_{3}$, followed by application of silane layer, produced high bond strength after composite or repair aging.
\end{abstract}

Keywords: Composite Resins; Dental Restoration Failure; Dental Restoration Repair; Dental Bonding.

\section{Introduction}

Resin-based composite restorations have a mean yearly failure rate of $1.6 \%$, and the primary reasons for replacement are secondary caries and fractures. ${ }^{1,2}$ Recent clinical studies and meta-analyses have established that repair is an alternative to replacement of defective restorations and increases the longevity of restorations with minimal intervention. ${ }^{3,4,5}$ The total replacement of defective restorations may result in the loss of healthy dental structure and cause injury to the dentin-pulp complex. ${ }^{6,7}$ The concept of repair instead of restoration is part of the philosophy of minimally 
invasive dentistry, which aims to avoid repetitive restorative cycles. ${ }^{8}$ So, has brought into perspective the possibility of more conservative procedures that are based on preserving tooth structure.

Although the choice of a conservative procedure is appropriate, repairs require a specific surface treatment, as the interface bonding between new layers of resin and restoration decreases,,$^{9,10,11}$ mainly after water storage of composite. ${ }^{12,13,14,15,16,17,18,19}$ Different surface treatments are essential to increase the surface area and intermediate material wettability, resulting in intimate adaptation of interface resin/restoration and increased composite resin repair strength. ${ }^{9,20}$ The main methods used for repair include sandblasting with aluminum oxide $\left(\mathrm{Al}_{2} \mathrm{O}_{3}\right)_{1}^{11,14}$ application of an adhesive layer or silane, ${ }^{15,21}$ treatment with hydrofluoric acid ${ }^{21}$ or phosphoric acid, ${ }^{22}$ and surface roughening using diamond burs. ${ }^{23}$ In addition to surface treatment, aging of the composite has a crucial role in determining the bond strength of the repair. ${ }^{24}$ After polymerization of composite resin layers, the resin present in the unreacted methacrylate group and the amount of unsaturated double bonds decreased over time and prevented resin adhesion. ${ }^{25}$

Several studies have reported varied results in terms of the effectiveness of different repair protocols, and there is no consensus regarding the most suitable surface treatment for repair of composites. ${ }^{23,26,27,28,29,30,31,32}$ Moreover, such studies have analyzed the repair of composite resins for short period. ${ }^{25,28,29,30,31}$ Therefore, the present study aimed to evaluate the influence of different surface treatments and long-term composite aging on the bond strength of composite resin repair.

\section{Methodology}

\section{Specimen preparation}

The materials used in this study are listed in Table 1. Overall, 32 cylinder-shaped composite substrates were prepared using a silicone matrix (height, $4 \mathrm{~mm}$; diameter, $6 \mathrm{~mm}$ ), layered in 2-mm increments with the composite (Esthet-X, shade B2; Dentsply Caulk, Milford, USA). Each increment was condensed using a hand instrument and photoactivated at a maximum distance of $10 \mathrm{~mm}$ for 40 seconds with a light intensity of $600 \mathrm{~mW} / \mathrm{cm}^{2}$ (Single V; Bio Art,
São Carlos, Brazil). The last layer was covered with a transparent polyether strip and compressed using a glass slide to obtain a flat surface. After the slide was removed, the specimen was photoactivated with the polyether strip in contact with the surface of the layer. The composite cylinders were removed from the matrix, randomized in parallel groups (by Random program- https://www.random.org/) and divided into storage periods of 24 hours and 1 year (2 groups) and surface treatments (4 groups for each period) for a total of eight groups. Thereafter, composite cylinders were repaired and prepared to microtensile bond strength (beams) and divided again into storage periods of 24 hours and 1 year ( 2 groups) in artificial saliva, as shown in Figure (for a total of 16 groups).

\section{Surface treatment and repair procedures}

The groups received the following surface treatments:

$\mathrm{G}_{\text {control }}$ : Composite cylinders received no treatment before resin composite repair;

$\mathrm{G}_{\mathrm{Al} 2 \mathrm{O} 3}$ : An air spray of $25-50 \mu \mathrm{m}\left(\mathrm{Al}_{2} \mathrm{O}_{3}\right)$ particles; 220 Mesh (Bio Art, São Carlos, Brazil) was used to sandblast the specimen for $30 \mathrm{~s}$ perpendicular to the surface;

$\mathrm{G}_{\mathrm{Al2O3ad}}$ : After sandblasting, an adhesive resin layer was actively applied for $10 \mathrm{~s}$ (ScotchBond, 3MESPE, St Paul, USA) and photoactivated for $40 \mathrm{~s}$;

$\mathrm{G}_{\mathrm{Al2O} \text { sil }}$ : After sandblasting, a silane solution (Angelus, Londrina, Brazil) was applied for $1 \mathrm{~min}$ and air dried for $5 \mathrm{~s}$ from a distance of $5 \mathrm{~mm}$ to evaporate solvents.

After surface treatment, repairs were performed incrementally on the resin composites and photoactivated for $40 \mathrm{~s}$.

\section{Specimen aging and microtensile bond strength test}

Twenty-four hours after the repair procedure, repairs were sectioned in beams with an interface area of approximately $0.5 \mathrm{~mm}^{2}(0.7 \times 0.7 \times 8 \mathrm{~mm})$ by using a diamond disc at low speed under water cooling (Isomet; Buehler, USA), producing a total of approximately 16 beams per cylinder. Specimens were divided according to storage time in artificial saliva 24 hours and 1 year for the composite cylinder -and 
Table 1. Materials used in the study.

\begin{tabular}{|c|c|c|c|}
\hline Product & Composition & Methodology & Manufacturer \\
\hline Composite resin-esthet- $X$ & $\begin{array}{l}\text { BisEMA, TEGDMA, BisGMA } \\
\text { and filler: bariumalumino } \\
\text { fluoroborosilicate, glass with } \\
\text { nano-sized silicon, dioxide particles, } \\
\text { titanium dioxide, and silica }\end{array}$ & $\begin{array}{l}\text { Increments of } 2 \mathrm{~mm} \text { using a } \\
\text { silicone matrix, each increment was } \\
\text { condensed with a hand instrument } \\
\text { and light polymerized. }\end{array}$ & Dentsply-Caulk, Milford, USA \\
\hline Air spray: $\mathrm{Al}_{2} \mathrm{O}_{3}$ & $\mathrm{Al}_{2} \mathrm{O}_{3}-25-50 \mu \mathrm{m}(220 \mathrm{Mesh})$ & $\begin{array}{l}\text { Blasted for } 30 \text { s perpendicular to the } \\
\text { specimen surface. }\end{array}$ & Bio Art, São Carlos, Brazil \\
\hline $\begin{array}{l}\text { Hydrofluoridric } \\
\text { acid-condac porcelana }\end{array}$ & $\begin{array}{l}\text { Hydrofluoric acid (9.6\%), water, } \\
\text { thickener, tensoactive, pigment }\end{array}$ & $\begin{array}{l}\text { Applied for } 60 \mathrm{~s} \text {, rinsed off for } \\
60 \mathrm{~s} \text { and air dried for } 10 \mathrm{~s} \text { from a } \\
\text { distance of } 5 \mathrm{~mm} \text {. }\end{array}$ & FGM-Joinville, Brazil \\
\hline $\begin{array}{l}\text { Adhesive-adper } \\
\text { scotchbond multipurpose }\end{array}$ & $\begin{array}{l}\text { BisGMA, HEMA, tertiary amines and } \\
\text { photoinitiator }\end{array}$ & $\begin{array}{l}\text { Adhesive resin layer was actively } \\
\text { applied for } 10 \mathrm{~s} \text { and light cured. }\end{array}$ & 3M ESPE-St Paul, USA \\
\hline Silane- angelus & Silane and ethanol & $\begin{array}{l}\text { Applied during } 60 \mathrm{~s} \text { and air dried } \\
\text { for } 5 \mathrm{~s} \text { from a distance of } 5 \mathrm{~mm} \text { to } \\
\text { evaporate solvents. }\end{array}$ & Angelus-Londrina, Brazil \\
\hline Light-curing unit-single $\mathrm{V}$ & Light intensity: $600 \mathrm{~mW} / \mathrm{cm}^{2}$ & $\begin{array}{l}\text { Composite resin and adhesive was } \\
\text { light cured for } 40 \mathrm{~s} \text {. }\end{array}$ & Bio Art-São Carlos, Brazil \\
\hline
\end{tabular}

BisEMA: ethoxylated bisphenol A glycol dimethacrylate; TEGDMA: triethylene glycol dimethacrylate; BisGMA: bisphenol A glycerolate dimethacrylate; $\mathrm{Al}_{2} \mathrm{O}_{3}$ : aluminum oxide; $\mathrm{HEMA}$ : hydroxyethyl methacrylate.

according to the resin composite repair procedure and surface treatment $-\left(\mathrm{Al}_{2} \mathrm{O}_{3}\right),\left(\mathrm{Al}_{2} \mathrm{O}_{3}\right)$ with adhesive, and $\left(\mathrm{Al}_{2} \mathrm{O}_{3}\right)$ with silane (Figure). During the storage period, artificial saliva was replaced every 28 days. Each specimen was measured using a digital caliper and subjected to a microtensile bond strength test. Beams were positioned with cyanoacrylate resin (Loctite Power Flex Gel Control-Henkel Ltda., São Paulo, Brazil) in a device coupled to a universal test machine (EMIC DL-2000, São José dos Pinhais, Brazil) with a crosshead speed of $1 \mathrm{~mm} / \mathrm{min}$. To express the bond strength in megapascals (MPa), the load upon failure was recorded in Newtons $(\mathrm{N})$ and divided by the bond area $\left(\mathrm{mm}^{2}\right)$.

\section{Statistical analysis}

Two-way ANOVA was performed to measure interactions among surface treatment, storage time of composite cylinders, and repair. Student's t test was performed between storage composite cylinders (24 hours and 1 year) versus storage time of repair (24 hours and 1 year), with a level of significance of 0.05 .

\section{Results}

The results of microtensile bond strength tests are shown in Table 2 . The $\mathrm{G}_{\text {control }}$ group exhibited the lowest bond strength values compared with other groups, independent of the storage time for composite cylinders and repair $(24$ hours or 1 year; $p<0.05$ ). The highest microtensile bond strength value was noted in the $\mathrm{G}_{\mathrm{Al} 2 \mathrm{O} 3 \mathrm{ad}}$ group without aging of composite or repair (46.52 $\pm 10.09 \mathrm{MPa})$. Composites aged for 24 hours with 1 year of repair aging showed decreased microtensile bond strength - from $26.93 \pm 14.26$ to $10.45 \pm 4.66 \mathrm{MPa}(\mathrm{p}<0.001)$ in the $\mathrm{G}_{\text {control }}$ group and from $40.16 \pm 16.99$ to $25.37 \pm 8.59 \mathrm{MPa}(\mathrm{p}<0.001)$ in the $\mathrm{G}_{\mathrm{Al2O} 3}$ group. On the other hand, groups with $\mathrm{Al}_{2} \mathrm{O}_{3}$ and silane $\left(\mathrm{G}_{\mathrm{Al} 2 \mathrm{O} s \mathrm{il}}\right)$ or $\mathrm{Al}_{2} \mathrm{O}_{3}$ and adhesive $\left(\mathrm{G}_{\mathrm{Al2O} 3 \mathrm{ad}}\right)$ exhibited no decrease in microtensile strength values after 1 year of repair aging $(p=0.23$ and $p=0.09$, respectively). After 1 year of composite aging, none of the groups showed statistically significant differences 24 hours or 1 year after repair ( $p>0.05$ ).

Results of Student's t test are shown in Table 3. The composite cylinder storage time of 1 year before repair aging was statistically significant for the $\mathrm{G}_{\text {control }}, \mathrm{G}_{\mathrm{Al} 2 \mathrm{O} 3}$, and $\mathrm{G}_{\mathrm{Al} 2 \mathrm{O} 3 \mathrm{~d}}$ groups $(\mathrm{p}<0.05)$. However, composite cylinder aging was not statistically significant for the $G_{\text {Al2O3sil }}$ group ( $p>0.21$ ). Nonaged composite cylinders (24 hours) with 1 year of repair showed no difference when compared with aged composite cylinders (1 year) with 1 year of repair, independent of surface treatment $(p>0.05)$. 
One-year aging effects on microtensile bond strengths of composite and repairs with different surface treatments

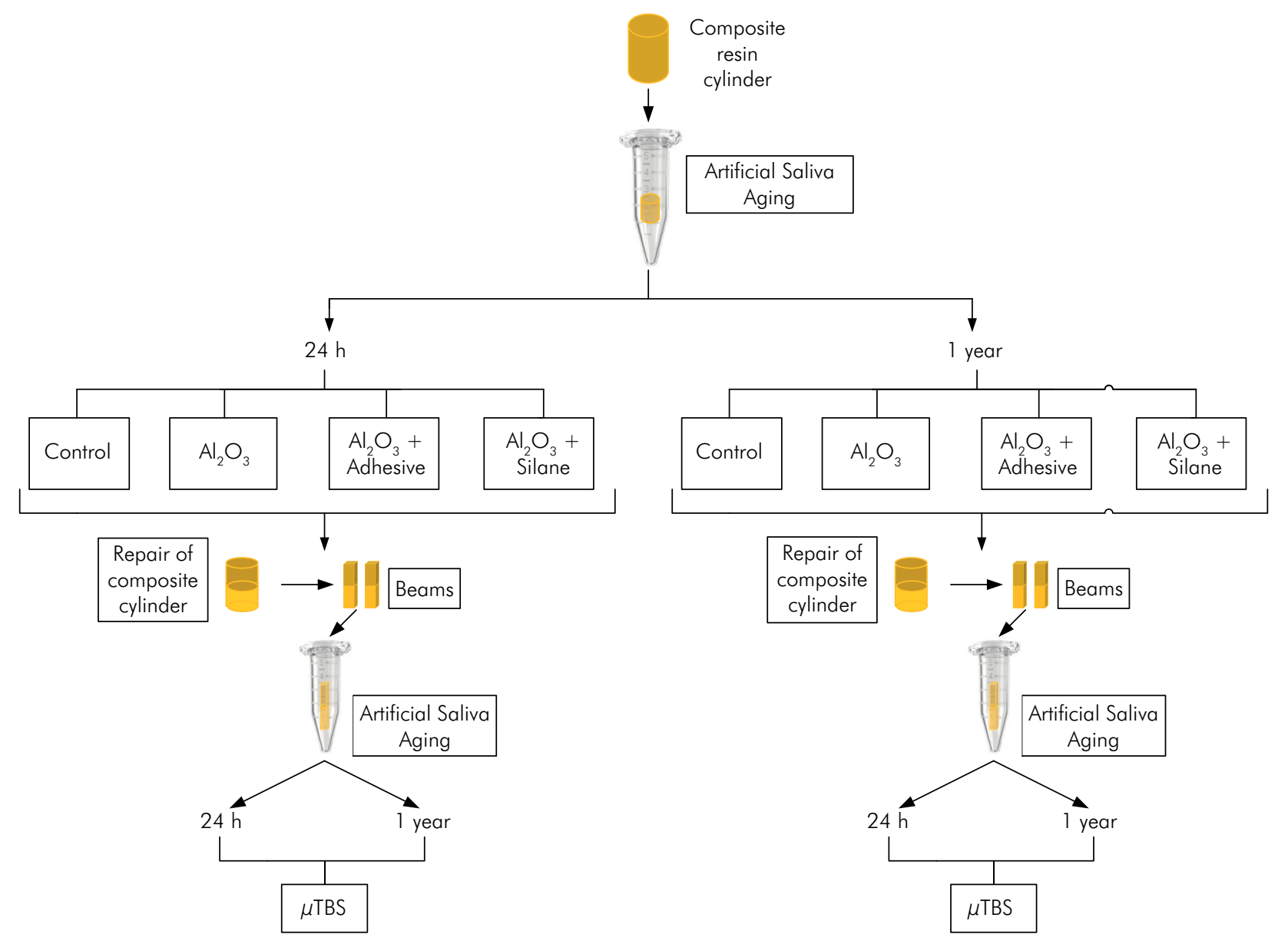

Figure. Methodological study design according to storage time (24 hours and 1 year) of composite resin and repair restoration.

Table 2. Date of microtensile bond strength of composite and repair according to storage time and surface treatment.

\begin{tabular}{|c|c|c|c|c|}
\hline \multirow{2}{*}{ Surface treatment } & \multicolumn{2}{|c|}{ Composite (24 hours) } & \multicolumn{2}{|c|}{ Composite ageing (1 year) } \\
\hline & Repair (24 h) & Repair Aging (1 y) & Repair (24 h) & Repair Aging (1 y) \\
\hline \multirow{2}{*}{$G_{\text {Control }}$} & $26.93 \pm 14.26$ & $10.45 \pm 4.66$ & $8.90 \pm 6.22$ & $11.18 \pm 4.86$ \\
\hline & $(\mathrm{Cl}: 21.82-32.03)^{\mathrm{Ba}}$ & $(\mathrm{Cl}: 7.91-12.98)^{\mathrm{Bb}}$ & $(\mathrm{Cl}: 5.94-11.85)^{\mathrm{Ba}}$ & $(\mathrm{Cl}: 8.99-13.36)^{\mathrm{Ba}}$ \\
\hline \multirow{2}{*}{$\mathrm{G}_{\mathrm{Al}_{2} \mathrm{O}_{3}}$} & $40.16 \pm 16.99$ & $25.37 \pm 8.59$ & $31.69 \pm 13.659$ & $30.48 \pm 13.86$ \\
\hline & $(\mathrm{Cl}: 34.35-45.96)^{\mathrm{Aa}}$ & $(\mathrm{Cl}: 18.99-31.74)^{\mathrm{Ab}}$ & $(\mathrm{Cl}: 26.53-36.84)^{\mathrm{Aa}}$ & $(\mathrm{Cl}: 24.23-36.72)^{\mathrm{Aa}}$ \\
\hline \multirow{2}{*}{$\mathrm{G}_{\mathrm{Al}_{2} \mathrm{O}_{3} \mathrm{ad}}$} & $46.52 \pm 10.09$ & $39.51 \pm 7.78$ & $37.76 \pm 8.19$ & $34.96 \pm 20.74$ \\
\hline & $(\mathrm{Cl}: 41.97-51.06)^{\mathrm{Aa}}$ & $(\mathrm{Cl}: 35.91-43.10)^{\mathrm{Aa}}$ & $(\mathrm{Cl}: 33.97-41.54)^{\mathrm{Aa}}$ & $(C l: 25.86-44.05)^{\mathrm{Aa}}$ \\
\hline \multirow{2}{*}{$\mathrm{G}_{\mathrm{Al}_{2} \mathrm{O}_{3 \mathrm{sil}}}$} & $42.0 \pm 15.13$ & $35.32 \pm 12.23$ & $32.90 \pm 5.38$ & $30.67 \pm 12.81$ \\
\hline & $(\mathrm{Cl}: 36.17-47.82)^{\mathrm{Aa}}$ & $(\mathrm{Cl}: 29.66-40.97)^{\mathrm{Aa}}$ & $(\mathrm{Cl}: 30.41-35.38)^{\mathrm{Aa}}$ & $(\mathrm{Cl}: 26.00-35.33)^{\mathrm{Aa}}$ \\
\hline
\end{tabular}

$\mathrm{G}_{\text {Control: }}$ the composite cylinders received no treatment prior to the resin composite repair; $\mathrm{G}_{\mathrm{Al}_{2} \mathrm{O}_{3}}$ : an air spray of $25-50 \mu \mathrm{m}$ aluminum

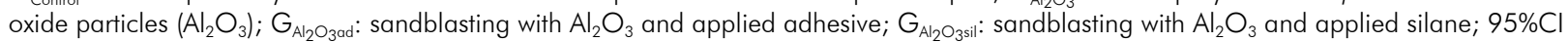
confidence intervals. Different capital letters indicates statistical difference in same column $(p<0.05)$. Different small letters indicates statistical difference in the same row $(p<0.05)$.

Power of performed test with $\alpha=0.05$ for composite (24 hours): storage time repair $(24 \mathrm{~h}$ ) $99 \%$, storage time repair ( 1 y) $100 \%$ and storage time repair $X$ surface treatment $12 \%$; for composite ageing (1 year): storage time repair $(24 \mathrm{~h}) 5 \%$, storage time repair (1 y) $100 \%$ and storage time repair $X$ surface treatment $5 \%$. 
Table 3. Mean and standard deviation $( \pm S D)$ of bond strength of composite and repair according to storage time of composite ageing.

\begin{tabular}{|c|c|c|c|c|}
\hline Treatment & Composite (24h)/ Repair (24h) & $\begin{array}{c}\text { Composite Aging (1y)/ Repair } \\
\text { (24h) }\end{array}$ & $\begin{array}{l}\text { Composite }(24 \mathrm{~h}) / \\
\text { Repair Aging (1y) }\end{array}$ & $\begin{array}{c}\text { Composite Aging (1y)/Repair } \\
\text { Aging (1y) }\end{array}$ \\
\hline$G_{\text {Control }}$ & $26.93 \pm 14.26^{a}$ & $8.90 \pm 6.22^{b}$ & $10.45 \pm 4.66^{\#}$ & $11.18 \pm 4.86$ \# \\
\hline $\mathrm{G}_{\mathrm{Al} 2 \mathrm{O} 3}$ & $40.16 \pm 16.99^{\circ}$ & $31.69 \pm 13.65^{b}$ & $25.37 \pm 8.59^{\#}$ & $30.48 \pm 13.86^{\#}$ \\
\hline$G_{\text {A12O3ad }}$ & $46.52 \pm 10.09^{a}$ & $37.76 \pm 8.19^{b}$ & $39.51 \pm 7.78^{\#}$ & $34.96 \pm 20.74^{\#}$ \\
\hline $\mathrm{G}_{\mathrm{Al} 2 \mathrm{O} \mathrm{sil}}$ & $42.0 \pm 15.13^{\circ}$ & $32.90 \pm 5.38^{a}$ & $35.32 \pm 12.23^{\#}$ & $30.67 \pm 12.81^{\#}$ \\
\hline
\end{tabular}

$\mathrm{G}_{\text {Control }}$ t the composite cylinders received no treatment prior to the resin composite repair; $\mathrm{G}_{\mathrm{Al}_{2} \mathrm{O}_{3}}$ : an air spray of $25-50 \mu \mathrm{m}$ aluminum oxide particles $\left(\mathrm{Al}_{2} \mathrm{O}_{3}\right) ; \mathrm{G}_{\mathrm{Al}_{2} \mathrm{O}_{3} \text { ad }}$ : sandblasting with $\mathrm{Al}_{2} \mathrm{O}_{3}$ and applied adhesive; $\mathrm{G}_{\mathrm{Al}_{2} \mathrm{O}_{3} \text { sil }}$ : sandblasting with $\mathrm{Al}_{2} \mathrm{O}_{3}$ and applied silane. Different letter and symbols indicates statistical difference in same row $(p<0.05)$.

\section{Discussion}

Composite resins have shown good clinical performance over 27 years of restorations with an annual failure rate of approximately $1.6 \% .{ }^{2}$ However, the annual failure rate of repaired composite restorations is $5.7 \%$ at 4 years. ${ }^{1}$ Several in vitro studies have investigated methods to repair existing restorations by using various surface treatments and coating layers without taking into account age of the composite to be repaired. In the present study, the type of surface treatment and the age of both composite cylinders and repair influenced the bond strength of the composite repair.

The influence of oral environment, $\mathrm{pH}$ changes, and chemical constituents of beverages, food, microorganisms, and body fluids result in chemical and mechanical degradation of composites. ${ }^{5}$ Restorative composites are not stable and continue to interact with the environment after polymerization. ${ }^{16}$ Based on findings of the present study, composite resin aging influenced the bond strength of repair in an artificial saliva environment. Hydrolytic degradation occurs during water diffusion through polymers, resulting in leaching of unreached monomers and soluble ions of the repairable surface ${ }^{17,18}$ Moreover, it could weaken the union between the filler and the resin matrix ${ }^{19}$ and increase internal porosity. Concurrently, water absorption determines hygroscopic expansion of resins in both volume and weight. ${ }^{16}$ These phenomena could lead to surface alterations that influence the bond strength of the repair.

Various methods are utilized to simulate aging of a resin composite, such as immersion in citric acid ${ }^{32}$ or saline solution..$^{11}$ The storage of composite cylinders in artificial saliva at $37^{\circ} \mathrm{C}$ for 1 year was used to simulate the composite degradation that occurs in the oral environment and leads to decreased repair bond strength. In the present study, composite resin aging resulted in lower bond strength, mainly without any surface treatment $\left(\mathrm{G}_{\text {control }}\right)$. A similar study that simulated aging of composite resin repairs with thermocycling reported decreased bond strengths among aged repaired composites that received different surface treatments. However, these results could be explained by nonsignificant aging of the resin composite to be repaired owing to the number of cycles used (6000 cycles) $)^{21}$ as it had already been proposed that 10.000 cycles correspond to approximately 1 year of in vivo functioning. ${ }^{24}$ After 1 year of storage, repair aging showed significantly decreased bond strength in the $G_{\text {control }}$ and $G_{\mathrm{Al} 203}$ groups ( $\left.p<0.05\right)$, although this decrease was not significant when the composite cylinders were aged for 1 year $(p>0.05)$ however, the statistical power was low. Thus, polymer degradation after 1 or 2 years is probably more superficial and was not significant effect in microtensile bond test.

One might assume that age of the resin composite to be repaired would be the main factor involved in maintaining bond strength of the repair. However, the surface treatment used significantly influences adhesion of the new restoration. Composite repair procedures that use intermediate unfilled resins utilize chemical bond formation, involving the matrix and filler particles, and better wettability of the new material. In the present study, application of $\left(\mathrm{Al}_{2} \mathrm{O}_{3}\right)$, silane, or an adhesive layer increased bond strength of the repair. According to available literature, surface treatments should aim for mechanical interlocking of the repair composite to be inserted. ${ }^{27}$ Even after 1 year of storage in artificial saliva, composite cylinder aging and repair aging were not influenced by hydrolytic degradation when the surface 
was sandblasted followed by application of an adhesive layer ( $\mathrm{p}>0.05)$. $\left(\mathrm{Al}_{2} \mathrm{O}_{3}\right)$ sandblasting has markedly increased the bond strength of repairs elsewhere $\mathrm{e}^{11,28,33}$ as it is capable of producing microretentions, thereby increasing the surface area to improve wetting and adhesion to the composite resin..$^{29,30}$ The adhesive penetrated into the microretentions of the composite surface with adequate wetting and maintained the mechanical properties of the interface after polymerization. ${ }^{31}$ The results of the $\mathrm{G}_{\text {A12O3ad }}$ group revealed that after 1 year of aging, the bond strength decreased significantly, from 46.52 \pm 10.09 to $37.76 \pm 8.19 \mathrm{MPa}$. Decreases in bond strength occurred due to adhesive degradation and solubility when the interface was exposed to organic solvents. ${ }^{34,35}$

Several studies have extensively investigated the application of an intermediate silane layer, leading to conflicting results. While the low viscosity, high wetting, and chemical affinity of silane to bond to inorganic fillers of composites could enhance the bond strength of the repair, ${ }^{23}$ application of a thicker silane layer could lead to greater hydrolytic degradation of the interface as well as decreased bond strength of repair after aging. ${ }^{36}$ However, in the present study, $\mathrm{G}_{\mathrm{A} 12 \mathrm{O} 3 \mathrm{sil}}$ (surface treatment with $\mathrm{Al}_{2} \mathrm{O}_{3}$ and silane) was the only group that maintained the

\section{References}

1. Opdam NJ, Bronkhorst EM, Loomans BA, Huysmans MC. Longevity of repaired restorations: a practice based study. J Dent. 2012;40(10):829-35. doi:10.1016/j.jdent.2012.06.007

2. Pallesen U, Dijken JW. A randomized controlled 27 years follow up of three resin composites in Class II restorations. J Dent. 2015;43(12):1547-58. doi:10.1016/j.jdent.2015.09.003

3. Fernández E, Martín J, Vildósola P, Oliveira Junior OB, Gordan V, Mjor I et al. Can repair increase the longevity of composite resins? Results of a 10-year clinical trial. J Dent. 2015;43(2):279-86. doi 10.1016/j.jdent.2014.05.015

4. Fernández EM, Martin JA, Angel PA, Mjör IA, Gordan VV, Moncada GA. Survival rate of sealed, refurbished and repaired defective restorations: 4-year follow-up. Braz Dent J. 2011;22(2):134-9. doi:10.1590/S0103-64402011000200008

5. Opdam NJ, Sande FH, Bronkhorst E, Cenci MS, Bottenberg $\mathrm{P}$, Pallesen $\mathrm{U}$ et al. Longevity of posterior composite restorations: a systematic review and meta-analysis. J Dent Res. 2014;93(10):943-9. doi:10.1177/0022034514544217 microtensile bond strength after aging of the composite cylinder (Table 3; $\mathrm{p}<0.05$ ). Thus, sandblasting of aged resin composites to be repaired could promote removal of the superficial mass of degraded resin, producing greater surface area. The silane layer applied after sandblasting could wet and penetrate the irregularities formed and maintain the mechanical properties of the interface even after aging. Moreover, the chemical bond with silane occurs following repair of aged resin composites, and silane has the ability to chemically bond with filler particles of the aged composite..$^{29,30}$

\section{Conclusion}

Aging of composite resins influences the microtensile bond strength of the restoration repair up to 1 year. Sandblasting with aluminum oxide followed by application of a silane layer produced high bond strength after composite aging and repair aging.

\section{Acknowledgments}

The authors gratefully acknowledge CAPES (Coordenação de Aperfeiçoamento de Pessoal de Nível Superior) for the scholarship (MOS and SBR).

6. Hunter AR, Treasure ET, Hunter AJ. Increases in cavity volume associated with the removal of class 2 amalgam and composite restorations. Oper Dent. 1995;20(1):2-6.

7. Demarco FF, Corrêa MB, Cenci MS, Moraes RR, Opdam

NJ. Longevity of posterior composite restorations: not only a matter of materials. Dent Mater. 2012;28(1):87-101. doi:10.1016/j.dental.2011.09.003

8. Mjör IA, Gordan VV. Failure, repair, refurbishing and longevity of restorations. Oper Dent. 2002;27(5):528-34.

9. Boyer DB, Chan KC, Reinhardt JW. Build-up and repair of light-cured composites: bond strength. J Dent Res 1984;63(10):1241-4. doi:10.1177/00220345840630101501

10. Costa TR, Serrano AM, Atman AP, Loguercio AD, Reis A. Durability of composite repair using different surface treatments. J Dent. 2012;40(6):513-21. doi:10.1016/j.jdent.2012.03.001

11. Papacchini F, Magni E, Radovic I, Mazzitelli C, Monticellia F, Goracci $C$ et al. Effect of intermediate agents and pre-heating of repairing resin on composite-repair bonds. Oper Dent. 2007;32(4):363-71. doi:10.2341/06-105 
12. Brendeke J, Ozcan M. Effect of physicochemical aging conditions on the composite-composite repair bond strength. J Adhes Dent. 2007;9(4):399-406.

13. Tezvergil A, Lassila LV, Vallittu PK. Composite-composite repair bond strength: effect of different adhesion primers. J Dent. 2003;31(8):521-5. doi:10.1016/S0300-5712(03)00093-9

14. Dall'oca S, Papacchini F, Radovic I, Polimeni A, Ferrari M. Repair potential of a laboratory-processed nano-hybrid resin composite. J Oral Sci. 2008;50(4):403-12. doi:10.2334/josnusd.50.403

15. Ozcan M, Alander P, Vallittu PK, Huysmans MC, Kalk W. Effect of three surface conditioning methods to improve bond strength of particulate filler resin composites. J Mater Sci Mater Med. 2005;16(1):21-7. doi:10.1007/s10856-005-6442-4

16. Yap AU, Wee KE. Effects of cyclic temperature changes on water sorption and solubility of composite restoratives. Oper Dent. 2002;27(2):147-53.

17. Ferracane JL. Hygroscopic and hydrolytic effects in dental polymer networks. Dent Mater. 2006;22(3):211-22. doi:10.1016/j.dental.2005.05.005

18. Ferracane JL. Elution of leachable components from composites. J Oral Rehabil. 1994;21(4):441-52. doi:10.1111/j.1365-2842.1994.tb01158.x

19. Malacarne J, Carvalho RM, Goes MF, Svizero N, Pashley DH, Tay FR et al. Water sorption/solubility of dental adhesive resins. Dent Mater. 2006;22(10):973-80. doi:10.1016/j.dental.2005.11.020

20. Rathke A, Tymina Y, Haller B. Effect of different surface treatments on the composite-composite repair bond strength. Clin Oral Investig. 2009;13(3):317-23. doi:10.1007/s00784-008-0228-2

21. Passos SP, Ozcan M, Vanderlei AD, Leite FP, Kimpara ET, Bottino MA. Bond strength durability of direct and indirect composite systems following surface conditioning for repair. J Adhes Dent. 2007;9(5):443-7.

22. Loomans BA, Cardoso MV, Opdam NJ, Roeters FJ, De Munck J, Huysmans MC et al. Surface roughness of etched composite resin in light of composite repair. J Dent. 2011;39(7):499-505. doi:10.1016/j.jdent.2011.04.007

23. Loomans BA, Cardoso MV, Roeters FJ, Opdam NJ, De Munck J, Huysmans MC et al. Is there one optimal repair technique for all composites? Dent Mater. 2011;27(7):701-9. doi:10.1016/j.dental.2011.03.013

24. Gale MS, Darvell BW. Thermal cycling procedures for laboratory testing of dental restorations. J Dent. 1999;27(2):89-99. doi:10.1016/S0300-5712(98)00037-2

25. Fawzy AS, El-Askary FS, Amer MA. Effect of surface treatments on the tensile bond strength of repaired water-aged anterior restorative micro-fine hybrid resin composite. J Dent. 2008;36(12):969-76. doi:10.1016/j.jdent.2008.07.014

26. Sharif MO, Catleugh M, Merry A, Tickle M, Dunne SM, Brunton $\mathrm{P}$ et al. Replacement versus repair of defective restorations in adults: resin composite. Cochrane Database Syst Rev. 2014;2(2):CD005971. doi:10.1002/14651858

27. Brosh T, Pilo R, Bichacho N, Blutstein R. Effect of combinations of surface treatments and bonding agents on the bond strength of repaired composites. J Prosthet Dent. 1997;77(2):122-6. doi:10.1016/S0022-3913(97)70224-5

28. Costa TR, Ferreira SQ, Klein-Júnior CA, Loguercio AD, Reis A. Durability of surface treatments and intermediate agents used for repair of a polished composite. Oper Dent. 2010r;35(2):231-7. doi:10.2341/09-216-L

29. Swift EJ Jr., LeValley BD, Boyer DB. Evaluation of new methods for composite repair. Dent Mater. 1992;8(6):362-5. doi:10.1016/0109-5641(92)90020-D

30. Oztas N, Alaçam A, Bardakçy Y. The effect of air abrasion with two new bonding agents on composite repair. Oper Dent. 2003;28(2):149-54.

31. Lucena-Martín C, González-López S, Navajas-Rodríguez de Mondelo JM. The effect of various surface treatments and bonding agents on the repaired strength of heat-treated composites. J Prosthet Dent. 2001;86(5):481-8. doi:10.1067/mpr.2001.116775

32. Valente LL, Sarkis-Onofre R, Gonçalves AP, Fernández E, Loomans B, Moraes R. Repair bond strength of dental composites: systematic review and meta-analysis. Int J Adhes Adhes. 2016;69:15-26. doi:10.1016/j.ijadhadh.2016.03.020

33. Ozcan M, Barbosa SH, Melo RM, Galhano GA, Bottino MA. Effect of surface conditioning methods on the microtensile bond strength of resin composite to composite after aging conditions. Dent Mater. 2007;23(10):1276-82. doi:10.1016/j.dental.2006.11.007

34. Collares FM, Ogliari FA, Zanchi CH, Petzhold CL, Piva E, Samuel SM. Influence of 2-hydroxyethyl methacrylate concentration on polymer network of adhesive resin. J Adhes Dent. 2011;13(2):125-9. doi: 10.3290/j.jad.a18781

35. Leitune VC, Collares FM, Trommer RM, Andrioli DG, Bergmann CP, Samuel SM. The addition of nanostructured hydroxyapatite to an experimental adhesive resin. J Dent. 2013;41(4):321-27. doi:10.1016/j.jdent.2013.01.001

36. Antonucci JM, Dickens SH, Fowler BO, Xu HH, McDonough WG. Chemistry of silanes: interfaces in dental polymers and composites. J Res Natl Inst Stand Technol. 2005;110(5):541-58. doi:10.6028/jres.110.081 